\title{
Journal of Black Studies
}

http://jbs.sagepub.com

\section{Crisis Communication, Race, and Natural Disasters \\ Patric R. Spence, Kenneth A. Lachlan and Donyale R. Griffin Journal of Black Studies 2007; 37; 539 \\ DOI: $10.1177 / 0021934706296192$}

The online version of this article can be found at:

http://jbs.sagepub.com/cgi/content/abstract/37/4/539

\author{
Published by: \\ (5) SAGE Publications \\ http://www.sagepublications.com
}

Additional services and information for Journal of Black Studies can be found at:

Email Alerts: http://jbs.sagepub.com/cgi/alerts

Subscriptions: http://jbs.sagepub.com/subscriptions

Reprints: http://www.sagepub.com/journalsReprints.nav

Permissions: http://www.sagepub.com/journalsPermissions.nav

Citations (this article cites 17 articles hosted on the

SAGE Journals Online and HighWire Press platforms):

http://jbs.sagepub.com/cgi/content/refs/37/4/539 


\title{
CRISIS COMMUNICATION, RACE, AND NATURAL DISASTERS
}

\author{
PATRIC R. SPENCE \\ Calvin College \\ KENNETH A. LACHLAN \\ Boston College \\ DONYALE R. GRIFFIN \\ Wayne State University
}

\begin{abstract}
This study compares differences in crisis preparation, informationseeking patterns, and media use on the basis of race in the aftermath of Hurricane Katrina. Surveys are collected from 935 Katrina evacuees relocated in different areas of the United States. Results indicate differences in crisis preparation and information seeking on the basis of race. Results also demonstrate a continued need to create messages encouraging crisis preparation, especially among at-risk subpopulations.
\end{abstract}

Keywords: crisis communication; Hurricane Katrina; evacuations; information seeking

Hurricane Katrina struck the Gulf Coast on August 29, 2005 , creating the largest natural disaster in U.S. history. Although the storm produced the largest amount of physical destruction in other areas of the Gulf Coast, the city of New Orleans received the most media attention because of the size and status of the city. Levees

\footnotetext{
AUTHORS' NOTE: Order of authorship was determined by a coin flip, as each author contributed equally to this article. The authors wish to thank graduate students Anirban Mukhopadhyay and Kenneth M. Sibal for their contributions with data entry. This material is based on work supported by the National Science Foundation (NSF) under Grant 0428216. Any opinions, findings, conclusions, or recommendations expressed in this article are those of the authors and do not necessarily reflect the views of the NSF. Please address all correspondence and inquiries to the first author at spencepa@calvin.edu.
} 
designed to protect the city failed after the Hurricane passed, causing New Orleans to flood. With much of the city already existing below sea level, this scenario came to be known as the "filling of the bowl." The flooding killed thousands, stranded more than 10,000 , and was the trigger event for a massive relief and evacuation effort. The storm also created a memorable media spectacle as those stranded in New Orleans waited on rooftops, in public centers, and in attics for relief amid toxic floodwaters, shortages of food, drinking water, and medical services (Adams, 2005).

Explanations exist concerning why this tragedy was so vast; others offer explanations concerning how these events could have been avoided or minimized. Since the hurricane, many have joined the media in expressing outrage at the government's response-or lack of response-particularly in an area with such a high concentration of low income minorities. Of the tens of thousands affected by the hurricane's damage, this study is particularly interested in the process by which racial minorities in the flood area prepared for the crisis and their willingness to evacuate the area. This study examines the role of crisis preparedness and willingness to evacuate among minority populations during the impact of Hurricane Katrina. Past research on disaster response has demonstrated differences in preparation, knowledge, and willingness to evacuate among minority populations and the poor (Gladwin \& Peacock, 1997). The first aim of this study is to determine if changes in evacuation behaviors have occurred in minority populations. The second portion of this study examines elements of information seeking and media choice with relation to race. The central focus of this study is the examination of whether differences exist on the bases of race in crisis preparation, media use, and information seeking.

\section{CRISIS COMMUNICATION}

Crisis is generally defined as a "a specific, unexpected, and non-routine event or series of events that create high levels of uncertainty and threaten or are perceived to threaten high priority goals," including security of life and property or the general individual or community well-being (Seeger, Sellnow, \& Ulmer, 1998, p. 233). 
Hurricane Katrina fits this definition and is more specifically a natural disaster of large proportions (Coombs, 1999). Although crises take many forms, communication scholars have typically examined them in organizational or political contexts (Sellnow, Seeger, \& Ulmer, 2002). In contrast, natural disasters have received less attention. This may be due to their classification as large-scale community or geographically based events, precipitated by natural processes that severely affect society or its subunits (Kreps, 1984; Quarantelli, 1978, Sellnow et al., 2002). Furthermore, the communication needs of racial minorities and the poor in crises have received even less attention, even though these are populations most often hit the hardest during a crisis (Baker, 2001; Bolin \& Bolton, 1986; Dash, Peacock, \& Morrow, 1997; Peacock \& Girard, 1997; Williams \& Olaniran, 2002).

Examples of crises include chemical or nuclear disasters (Bhopal Union Carbide and Three Mile Island), major plane crashes, space exploration catastrophes (Columbia), terrorist attacks such as 9/11, and public health threats, such as E. coli or the recent hepatitis scare associated with Chi Chi's restaurant. Crises are also marked by high levels of potential danger (e.g., loss of life) and fast actions by public officials to counteract the potential threat and are unanticipated events that throw off the everyday patterns of life.

Crisis communication aims at preventing or lessening the negative outcomes resulting from a crisis, often crisis communication has an informative function. Such messages encourage the receiver to take some action to avoid a possible threat or harmful effect and to create a rational understanding of the risk, a persuasive function. The crisis message makes clear directions on the current state regarding the crises and what actions should now be taken.

\section{CRISIS PREPAREDNESS AND KATRINA}

Often when the public receives risk or crisis messages, they make risk assessments based on sensory perception (Helsloot \& Ruitenberg, 2004) particularly in the case of natural disasters. The risks associated with natural disasters are typically very visible and generally well understood. Therefore, if the public believes it is necessary and has received appropriate information in a timely 
manner, it is reasonable to expect that they will take action to protect themselves.

Some studies have demonstrated different results when examining race, class, and crisis preparation. It was found that evacuation before Hurricane Andrew was lowest among African Americans and Hispanics (Gladwin \& Peacock, 1997; Peacock, 2003; Sattler et al., 1995). Perry and Mushkatel (1986) indicate that awareness of a potential risk and the preparation for that risk can be related to particular demographics. For example, nonminorities and people of higher socioeconomic status are usually better prepared for disasters and serious accidents than others. Minorities may be at a disadvantage in terms of crisis preparedness because they are more likely to have lower incomes, have nonexpendable finances, and be unemployed (Gladwin \& Peacock, 1997). They may live in more vulnerable areas and may not have access to transportation. The variability in crisis preparedness across ethnicity and socioeconomic status has been demonstrated in previous research. Because past studies have demonstrated a tendency for minorities to be reluctant, less likely, or able to evacuate, the following research questions are offered:

Research Question 1: Were minority populations less likely to evacuate before Hurricane Katrina?

Research Question 2: What demographic differences existed in crisis preparation?

\section{MEDIA USE AND INFORMATION SEEKING}

When crisis events run the likelihood of presenting danger, individuals engage in information seeking (Brashers et al., 2000). They typically seek information from a variety of sources and will constantly update their information. Mass media can be expected to be the dominant source (Murch, 1971), as the media are generally thought to be a valuable and timely source of information (Heath, Liao, \& Douglas, 1995). Once information is received, it facilitates two sets of remedial processes (Seeger, Sellnow, \& Ulmer, 2003). First, this information will allow individuals to observe the behavior of others in the given situation. Mediated information can also 
be used at this time as a means to reduce tension and alleviate anxiety. Through hearing the accounts of others who have experienced the event, individuals are able to make sense of a highly equivocal situation (Weick, 1995). Second, information will facilitate more specific remedial responses (Seeger et al., 2003). An individual's ability to take some action during the crisis brings about a sense of empowerment, allowing the individuals to feel as though they have some control in the situation. The idea that crisis messages should create some sense of self-efficacy is well represented in the literature (Seeger et al., 2003; Witte, 1994).

Race has not been examined as a predicator of information seeking. Although it has been demonstrated that racial minorities and the poor are typically hit hardest during natural disasters, the topic of information acquisition has gone unexamined. No research, it seems, has compared the information-seeking patterns of different racial/ethnic groups in times of a crisis or situations involving risk. Research has found that individuals are more likely to direct information seeking toward those who possess similar attributes (Ibarra, 1993, 1995); it then follows that racial/ethnic minorities will have fewer homophile others to target for information and fewer media outlets that are perceived as similar. Because little is known in this area, the following research question is offered:

Research Question 3: To what extent was information seeking during Hurricane Katrina different based on racial demographics?

Crisis research after 9/11 indicated the importance of interpersonal networks in information diffusion. In a sample of suburban Michigan residents, it was found that half of the respondents first learned about the terrorist attacks from someone else, whereas 33\% found out from television and only $15 \%$ found out from radio (Greenberg, Hofschire, \& Lachlan, 2002). The same data also reveal that during the next 2 days, $88 \%$ of those respondents reported that television was their most important source for gaining information about the attacks, rescue and aid efforts, and political responses. A full $94 \%$ of the sample indicated being aware of the attacks within 2 hours of the first plane crashing into the World Trade Center. Several years of research has also demonstrated support for television and 
interpersonal networks as the sources most commonly used to acquire information concerning important news events (Bracken, Jeffres, Neuendorf, Kopfman, \& Moulla, 2005; Deutschman \& Danielson, 1960; Greenberg, 1964; Spitzer \& Spitzer, 1965).

However, research has found that racial and ethnic minorities are less likely to accept a risk or warning message as credible without confirmation of the message from others (specifically interpersonal networks), thus causing a delay in response time (Fothergill, Maestas, \& Darlington, 1999; Lindell \& Perry, 2004). In the wake of the anthrax attacks, studies revealed distrust of government messages by racial minority groups, results that are troubling when adherence to government directives may be essential to issues of health and safety (Braveman, Egerter, Cubbin, \& Marchi, 2004; Quinn, Thomas, \& McAllister, 2005). Although past research indicated differences in the use of television for entertainment (Appiah, 2001; Initiative Media, 2003), there is no research to suggest racebased differences in media use for information seeking in a crisis. The following hypotheses are offered:

Hypothesis 1: There will be no differences between Caucasians and minorities in use of television as the primary medium used to learn about evacuation notices.

Hypothesis 2: Interpersonal channels will be reported more important among minorities regarding evacuation information.

Another area that has not received much attention is the use of new media among the poor and racial minorities. A study by Bracken et al. (2005) examined the use of new media in the context of a crisis. They noted that the diffusion processes may be altered with the emergence of a changing media environment. Therefore, when a crisis erupts during the business day, mobile telephones may replace interpersonal interactions as people call friends and family to obtain information. This may still constitute an interpersonal channel but one that is technologically mediated. Furthermore, e-mail and the Internet may also emerge as information sources.

Though new media channels were not found to be more important in news diffusion, the Bracken et al. (2005) study looked at new media and news diffusion after an exploding crisis event (Kepplinger, Brosius, Staab, \& Linke, 1989). Though an 
examination of new media use during a crisis with immediate, noticeable, widespread abnormalities and trigger events is valuable, Hurricane Katrina does not fit this definition. The storm was tracked for days, and it was the center of much news coverage. Because the trigger event of this type of crisis is much longer in duration, new media may emerge as a viable option for gaining information about the evacuation. Furthermore, because of the absence of local news for refugees in the aftermath of the hurricane, new media may have emerged as an important information medium after the hurricane. Given the gap in our knowledge of new media use during crises with prolonged trigger events, the following research question is offered:

Research Question 4: How important were new media and cellular telephones relative to interpersonal and traditional media channels before and after Hurricane Katrina?

\section{METHOD}

\section{PARTICIPANTS AND MEASURES}

Surveys were collected from Katrina refugees in relief centers in Cape Cod, Massachusetts; Lansing, Michigan; the Houston Astrodome; and several aid centers in Texas. They were collected during the course of 5 weeks immediately following the evacuation. In all, 964 surveys were completed, of which 935 were usable. ${ }^{1}$

\section{DEMOGRAPHIC VARIABLES}

Four items addressed demographics. Age was recorded simply as a continuous variable. Participants identified themselves as African American, Caucasian, or Other and as male or female. Finally, income was assessed though categorical measures. These categories included less than $\$ 10,000 ; \$ 10,000$ to $\$ 14,999 ; \$ 15,000$ to $\$ 19,999 ; \$ 20,000$ to $\$ 24,999 ; \$ 25,000$ to $\$ 29,999 ; \$ 30,000$ to $\$ 34,999 ; \$ 35,000$ to $\$ 39,999 ; \$ 40,000$ to $\$ 44,999 ; \$ 45,000$ to $\$ 49,999 ; \$ 50,000$ to $\$ 59,999 ; \$ 60,000$ to $\$ 74,999 ; \$ 75,000$ to $\$ 99,000$; and more than $\$ 100,000$. 


\section{CRISIS PREPARATION}

Two yes/no items measured the respondents' efforts to prepare for a disaster of this kind. The first item addressed emergency preparation in the home and was phrased "Before the hurricane, did you prepare an emergency kit or emergency supplies?" The second item addressed evacuation efforts, phrased as "Did you have any escape or preparation plan at all in mind this hurricane season?" A related item also asked "Did you evacuate before the storm hit?"

\section{INFORMATION SOURCES}

A series of items asked respondents to "indicate how you first learned of evacuation notices" from among 10 categories. These included friends/acquaintances, face-to-face interaction with a stranger, telephone call, written notice, an official (e.g., police), radio, television, newspaper, Internet or e-mail, or other. Similar yes/no questions asked if respondents received information through these sources after the evacuation. Respondents were also asked to indicate whether radio, television, and interpersonal exchanges were very important, important, or not important in obtaining information about the hurricane before it began to affect the area.

\section{RESULTS}

Research Questions 1 and 2 attempted to identify differences across ethnicity in terms of evacuating before the storm and crisis preparation. Cross-tabulation analyses reveal substantive differences between African American, Caucasian, and other non-White evacuees. Approximately $64.5 \%$ of the African American respondents reported evacuating before the storm, as compared to $85.5 \%$ of the Caucasian respondents and $82.9 \%$ of other non-White evacuees, $\chi^{2}(2)=18.67, p<.001, \phi=.143$. Although differences were not detected for the item addressing the preparation of an emergency kit, differences did emerge across the variable addressing whether respondents had an evacuation plan in place. Although $49.1 \%$ of the Caucasian respondents had prepared an escape plan 
ahead of time, only $31.4 \%$ of the African American respondents and $38.6 \%$ of the other non-White respondents reported having such a plan in place, $\chi^{2}(2)=8.28, p<.02, \phi=.100$.

Research Question 3 addressed the extent to which informationseeking habits might differ across ethnicity. To do this, a series of one-way ANOVA analyses explored differences in the mean scores across the items addressing the extent to which respondents placed importance on obtaining information concerning the scope of the storm's damage, government responses, food and water distribution, evacuation, shelters, rescue operations, the larger impact of the storm, who was affected by the storm, friends and family, and where to go for health care or medicine. The results indicate significant differences for information about evacuation, $F(2,803)=4.16, p<.02$, and information about shelter, $F(2,818)=4.88, p<.008$. Post hoc comparisons using least squared difference revealed that African American respondents were more likely than Caucasian respondents to seek out information concerning evacuation $(p<.016)$ and shelter $(p<.008)$.

Hypothesis 1 posited that differences would not exist across ethnicity in terms of reliance on television as the primary means of obtaining information, whereas Hypothesis 2 predicted that nonWhites would report placing greater importance in interpersonal communication as a source of evacuation information. Crosstabulation analyses support both hypotheses. Differences were not detected for the item asking whether respondents considered television to be very important, important, or not important, as $85.0 \%$ of the African American respondents, $80.4 \%$ of the Caucasian respondents, and $85.9 \%$ of the other non-White respondents considered television very important, $\chi^{2}(4)=1.82, p<.769, n s$. However, the data support the notion that interpersonal information may be a more critical source of information to minority victims, as only $56.4 \%$ of the Caucasian evacuees reported interpersonal information as very important, as opposed to $74.6 \%$ of the African American respondents and $77.1 \%$ of the other non-White respondents, $\chi^{2}(4)=10.00, p<.04, \phi=.11$.

Research Question 4 investigated the importance of new media and cellular phones relative to interpersonal and mediated channels. Simple descriptive analyses of the items addressing whether 
respondents learned of the evacuation through these channels and used them after the evacuation to obtain more information are perhaps the best means to evaluate this research question. The results indicate that very few respondents learned of the evacuation from a phone call, as this accounted for only $11.5 \%$ of the African American respondents, $10.9 \%$ of the Caucasian evacuees, and $15.3 \%$ of the other non-White respondents. The numbers for the Internet are incredibly low; across the entire sample, only three respondents reported finding out about the evacuation from a Web site or e-mail.

However, cell phones and the Internet do emerge as a frequently used information source for postcrisis information. A total of $78.7 \%$ the African American respondents, $82.1 \%$ of the Caucasian respondents, and $77.3 \%$ of the other non-White respondents reported using a cell phone after the evacuation to obtain information. African Americans (55.7\%) were less likely than Caucasians $(75.7 \%)$ or other non-Whites $(71.4 \%)$ to use the Internet as a source of postevacuation information; these proportions are, however, fairly high and indicative of the importance of these media for obtaining information after the crisis.

\section{DISCUSSION}

This study examined the manifest differences in crisis preparation, information seeking, and media use based on race. Many studies exist that focus on variable analytic racial differences (Houston, 2002), however the goal of this study is not to place emphasis on differences for the means of separation but rather to both demonstrate that differences exist and to identify the most needed messages and means for targeting those messages.

These results provide useful information concerning crisis preparation, information needs, and use after Hurricane Katrina. The data from this study support the notion that with race comes advantages in preparation and ability to evacuate. Past literature has supported the notion that in general nonminority populations are better prepared for disasters than others (Perry \& Mushkatel, 1986; Tierney, 1989). The current data provide further evidence of differences across race in 
terms of crisis preparedness and suggest the need for a research program targeting messages concerning crisis preparedness and proactive disaster measures at members of these groups. Given that emphasis on preparation by agencies such as the Federal Emergency Management Administration and the Department of Homeland Security is increasing, this conclusion may have important implications regarding how to motivate planning.

Information-seeking results indicated that in general African Americans were significantly more likely to engage in information seeking. Furthermore, they were more likely to seek out information concerning shelter and evacuation. Several factors may have contributed to the above findings, and sensitivity to these factors needs to be taken into consideration in future plans for crisis preparation. Perhaps part of the explanation for these differences can be explained through the relationship between motivation and information seeking. Motivation and interest influence the way information is used and critically evaluated. The more interested an individual has in a topic, the more information he or she will seek about it. Because people have a limited capacity for assimilating new information, particular attention is paid to information that can be related to previous knowledge. Previous studies suggest that African Americans are more likely than others to indicate a distrust of institutions of government to protect the public health and safety (Burby \& Strong, 1997). Given that many of the items reported could be classified as necessities for health and safety, distrust in government may have been the underlying motivation. However, the main explanation goes back to having the ability and information to prepare for and react to a crisis. Minorities and the poor were hit hardest during Katrina, and after the storm was over, safety and physiological needs may have been more important to these groups, because Caucasians and the wealthy already had provisions in place to meet these needs (Maslow, 1954). These results suggest that race may be worth considering when crafting risk and postcrisis messages to ensure that safety and physiological concerns are met.

It was hypothesized that Caucasians and minorities would both use television as the primary medium to learn about evacuation notices while interpersonal channels would be reported more important among minorities. Consistent with hypotheses, there was 
no difference in television use between minorities and Caucasians. Mass media, specifically television, are usually the dominant source for information acquisition (Murch, 1971; Spence et al., 2006), possibly because the media are generally considered valuable and timely sources of information (Heath et al., 1995). Moreover, media are generally accessible even during a crisis, and in the case of Katrina, these messages were being broadcast before the storm hit, making televisions accessible. Moreover, interpersonal channels were of more importance to minorities when compared with Caucasians. This suggests that if concern for the evacuation and safety does exist, then government agencies need to work with minority community leaders to create programs that will use existing interpersonal networks to plan and educate for issues of evacuation.

New media were not used as a means to obtain information prior to Katrina. One potential reason for the nonuse of new media can be traced to the ecological parameters of this type of natural disaster. High winds, flooding, and storm surge knocked out power lines, transformers, and cell phone towers that would have been essential to carry out these types of interactions. In fact, for the most part, the entire telecommunication infrastructure of New Orleans was knocked offline as the storm approached. Perhaps the lack of new media and cell phone use can be accounted for by the simple unavailability of the service rather than a conscious choice not to use such media. The use of effectiveness of new media as a means of crisis communication should be a focus of future studies.

However, after Katrina, cell phones and the Internet do emerge as frequently used sources of information. At this time, respondents would have been relocated and new media may have been their only means to obtain information about friends, family, and future plans. There was little difference in use of cell phones with relation to race, but Caucasians and other non-Whites were more likely to use the Internet than African Americans. New media may not have yet reached a point of diffusion and adoption to be seriously considered as an emergency medium at the present point in time. Regardless, the data suggest that new media have not yet reached the point of usefulness that traditional media displays before a crisis and should be used as a secondary focus for information 
distribution. However, new media may serve a useful and essential role in postcrisis message disbursement. Further research should examine the role of new media and postcrisis needs.

\section{LIMITATIONS}

Important limitations exist that should be considered in interpreting these results. First, the data were collected over an uneven timeframe; some participants responded hours after they were evacuated, some days, and some after weeks. This was, however, purely a result of the complex and time-consuming process of locating and interviewing hurricane evacuees. Data collection during crises is very complex. Future efforts should seek to obtain audience responses at one time point, and as quickly as possible, to reduce the likelihood of hindsight bias and memory distortion in the responses.

Second, although some of the results can be applied to different types of crisis scenarios, caution should be used when making such decisions. Evacuations during different crisis types will have different times of response. However, these data are useful in its outline of inequalities to crisis preparation and issues of evacuation.

\section{FUTURE DIRECTIONS}

Although this study examined Hurricane Katrina, not all the results are hurricane specific. Many are applicable to other crisis situations, and further research needs to examine issues of evacuation, information seeking, and media choice to provide practitioners with stronger suggestions about crisis response and message design.

Several issues may contribute to racial differences in response to evacuation notices. This study reported results around the variables of race. The role of the factors in promoting evacuation needs further research. Furthermore, differences emerged in information seeking and media use that should prove helpful in message design and placement. Discovering how to best direct and construct messages based on these differences is a worthwhile area of study. Another benefit could be to examine the issues of race from a critical perspective, looking specifically at 
how race and socioeconomic status contribute to access to information and resources for evacuation.

\section{CONCLUSION}

The need for effective crisis and risk messages is evident. As crises are occurring more frequently and becoming larger in scope, frequency, and harm, the need for these messages increases correspondingly. This increasing nature of crises has contributed to the raising concerns about the best ways citizens can obtain information about crises and the best behaviors in which they can engage. Although there is much left to learn about communication, risk, and crisis, the results of this study may shed light on design and placement elements that minimize the risk, duration, and harm created by a crisis event.

\section{NOTE}

1. Although 935 surveys were identified as usable, in many cases usable surveys contained a substantive amount of missing data. For this reason, several of the analyses on the following pages have less than 700 valid cases.

\section{REFERENCES}

Adams, S. (2005). Learning the lessons of Katrina for the unexpected tomorrow. Risk Management, 52, 24-30.

Appiah, O. (2001). Black, White, Hispanic and Asian-American adolescents' responses to culturally embedded ads. The Howard Journal of Communications, 12, 29-48.

Baker, G. (2001). Race and reputation: Restoring image beyond the crisis. In R. L. Heath \& G. Vasquez (Eds.), Handbook of public relations (pp. 513-520). Thousand Oaks, CA: Sage.

Bolin, R. C., \& Bolton, P. (1986). Race, religion, and ethnicity in disaster recovery. Boulder: University of Colorado Press.

Bracken, C. C., Jeffres, L., Neuendorf, K. A., Kopfman, J., \& Moulla, F. (2005). How cosmopolites react to messages: America under attack. Communication Research Reports, 22, 47-58.

Brashers, D. E., Neidig, J. L., Haas, S. M., Dobbs, L. K., Cardillo, L. W., \& Russell, J. A. (2000). Communication in the management of uncertainty: The case of persons living with HIV or AIDS. Communication Monographs, 67(1), 63-84. 
Braveman, P., Egerter, S., Cubbin, C., \& Marchi, K. (2004). An approach to studying social disparities in health and health care. American Journal of Public Health, 94, 2139-2148.

Burby, R., \& Strong, D. (1997). Coping with chemicals: Blacks, Whites, planners, and industrial pollution. Journal of American Planning Association, 63, 469-480.

Coombs, W. T. (1999). Ongoing crisis communication: Planning, managing, and responding. London: Sage.

Dash, N., Peacock, W. G., \& Morrow, B. H. (1997). And the poor get poorer: A neglected black community. In W. G. Peacock, B. H. Morrow, \& H. Gladwin (Eds.), Hurricane Andrew: Ethnicity, gender and sociology of disasters (pp. 206-225). London: Routledge.

Deutschman, P. J., \& Danielson, W. A. (1960). Diffusion of knowledge of a major news story. Journalism Quarterly, 37, 345-355.

Fothergill, A., Maestas, E. G., \& Darlington, J. D. (1999). Race, ethnicity and disasters in the United States: A review of the literature. Disasters, 23, 156-173.

Gladwin, H., \& Peacock, W. G. (1997). Warning and evacuation: A night for hard houses. In W. G. Peacock, B. H. Morrow, \& H. Gladwin (Eds.), Hurricane Andrew: Ethnicity, gender and sociology of disasters (pp. 52-74). London: Routledge.

Greenberg, B. S. (1964). Diffusion of news of the Kennedy assassination. Public Opinion Quarterly, 28, 225-231.

Greenberg, B. S., Hofschire, L., \& Lachlan, K. (2002). Diffusion, media use and interpersonal communication behaviors. In B. S. Greenberg (Ed.), Communication and terrorism (pp. 3-16). Cresskill, NJ: Hampton Press.

Heath, R. L., Liao, S., \& Douglas, W. (1995). Effects of perceived economic harms and benefits on issue involvement, information use and action: A study in risk communication. Journal of Public Relations Research, 7, 89-109.

Helsloot, I., \& Ruitenberg, A. (2004). Citizen response to disasters: a survey of literature and some practical implications. Journal of Contingencies and Crisis Management, $12,98-110$.

Houston, M. (2002). Seeking difference: African Americans in interpersonal communication research, 1975-2000. The Howard Journal of Communication, 13, 25-41.

Ibarra, H. (1993). Network centrality, power, and innovation involvement: Determinants of technical and administrative roles. Academy of Management Journal, 36, 471-501.

Ibarra, H. (1995). Race, opportunity, and diversity of social circles in managerial networks. Academy of Management Journal, 38, 673-703.

Initiative Media. (2003). African American television viewing study. New York: Initiative Worldwide.

Kepplinger, H. M., Brosius, H. B., Staab, J., \& Linke, G. (1989). Instrumentelle aktualisierung. Grundlagen einer theorie publizistischer konflikte [Instrumental actualization. Fundamentals of a theory of publicistic conflicts]. In M. Kasse \& W. Shulz (Eds.), Massenkommunikation. Theorien, methoden, befunde (pp. 199-220). Wiesbaden, Germany: Westdeutscher Verlag.

Kreps, G. A. (1984). Sociological inquiry and disaster research. In R. E. Turner \& J. F. Short, Jr. (Eds.), Annual review of sociology (pp. 309-330). Palo Alto, CA: Annual Reviews.

Lindell, M. K., \& Perry, R. W. (2004). Communicating environmental risk in multiethnic communities. Thousand Oaks, CA: Sage.

Maslow, A. H. (1954). Motivation and personality. New York: Harper.

Murch, A. W. (1971). Public concern for environmental pollution. Public Opinion Quarterly, 35, 100-106.

Peacock, W. G. (2003). Hurricane mitigation status and factors influencing mitigation status among Florida's single-family homeowners. Natural Hazards Review, 4, 149-158. 
Peacock, W. G., \& Girard, G. (1997). Ethnic and racial inequalities in hurricane damage and insurance settlements. In W. G. Peacock, B. H. Morrow, \& H. Gladwin (Eds.), Hurricane Andrew: Ethnicity, gender and sociology of disasters (pp. 171-190). London: Routledge.

Perry, R. W., \& Mushkatel, A. H. (1986). Minority citizens in disasters. Athens: University of Georgia Press.

Quarantelli, E. L. (1978). Disasters: Theory and research. Beverly Hills, CA: Sage.

Quinn, S. C., Thomas, T., \& McAllister, C. (2005). Postal workers' perspectives on communication during the anthrax attack. Biosecurity and Bioterrorism, 3, 207-215.

Sattler, D. N., Sattler, J. M., Kaiser, C., Hamby, B. A., Adams, M., Love, L., et al. (1995). Hurricane Andrew: Psychological distress among shelter victims. International Journal of Stress Management, 2, 133-143.

Seeger, M. W., Sellnow, T. L., \& Ulmer, R. R. (1998). Communication, organization, and crisis. In M. E. Roloff (Ed.), Communication yearbook, 21 (pp. 231-276). Thousand Oaks, CA: Sage.

Seeger, M. W., Sellnow, T., \& Ulmer, R. R. (2003). Communication and organizational crisis. Westport, CT: Praeger.

Sellnow, T., Seeger, M., \& Ulmer, R. R. (2002). Chaos theory, informational needs and the North Dakota floods. Journal of Applied Communication Research, 30, 269-292.

Spence, P. R., Westerman, D., Skalski, P., Seeger, M., Sellnow, T., \& Ulmer, R. R. (2006). Gender and age effects on information seeking after 9/11. Communication Research Reports, 23.

Spitzer, S. P., \& Spitzer, N. S. (1965). Diffusion of the news of the Kennedy and Oswald deaths. In B. S. Greenberg \& E. B. Parker (Eds.), The Kennedy assassination and the American public: Social communications in crisis (pp. 99-111). Stanford, CA: Stanford University Press.

Tierney, K. J. (1989). The social and community contexts of disaster. In R. Gist \& R. Lubin (Eds.), Psychosocial aspects of disaster (pp. 11-39). New York: John Wiley and Sons.

Weick, K. (1995). Sensemaking in organizations. Thousand Oaks, CA: Sage.

Williams, D. E., \& Olaniran, B. A. (2002). Crisis communication in racial issues. Journal of Applied Communication Research, 30(4), 293-313.

Witte, K. (1994). Generating effective risk messages: How scary should your risk communication be? In B. Burleson (Ed.), Communication yearbook, 18 (pp. 229-254). Thousand Oaks, CA: Sage.

Patric R. Spence (PhD, Wayne State University, 2005) is an assistant professor in the Department of Communication Arts \& Sciences at Calvin College.

Kenneth A. Lachlan (PhD, Michigan State University, 2003) is an assistant professor in the Communication Department at Boston College.

Donyale R. Griffin (PhD, Howard University, 2003) is an assistant professor at Wayne State University. 